\author{
А. В. Гура \\ Институт славяноведения РАН \\ Москва, Россия \\ avgura@mail.ru
}

\title{
Об одном архаическом способе символизации в культуре
}

В традиционном и обыденном сознании присутствует устойчивая ассоциация свадьбы с дракой, ссорой. Существует расхожее мнение носителей народной традиции, что свадьба не обходится без драки. Такое сближение имеет и ритуальное выражение: у польских пастухов Западных Бескид один из обязательных эпизодов игры в свадьбу драка в корчме после венчания. Почему эти понятия находятся в постоянной коннотативной связи со свадьбой? Возможно, потому, что в конце свадьбы допускается разгул, бесчинства? Или потребление алкоголя вызывает пьяные ссоры? Попытки ответить на этот вопрос давались разные. А. А. Потебня отмечал символическую связь женитьбы и пира (в том числе свадебного) с битвой. Другие видели в имитации драки на свадьбе реликт насильственного умыкания. Но ни одна из этих трактовок не выглядит вполне убедительной. Подобное восприятие свадьбы, как кажется, объясняется проще и лежит в иной плоскости: оно отталкивается не от каких-либо реальных особенностей свадьбы, которые осмысляются путем логического сближения их со ссорой или дракой, а определяется формальным, фонетическим созвучием соответствующих слов. Акустическая близость слов формирует символическую связь стоящих за ними понятий. Названиям свадьбы свад(b) ба и свар(ь)ба созвучны соответственно свада и свара, обозначающие ссору, вражду, драку. Подобные анафорические созвучия ярко представлены в жанре снотолкований: «Свадьба (сва́бда) - будет драка (cва́да)» (у болгар Баната); «Свадьба (свадба) означает ссору (свађу)» (у сербов Шумадии); «Сварьба - к сваре» (в Ярославской губ.).

Снотолкования - один из видов прорицаний, а фонетические созвучия, на которых они строятся, представляют собой род вербальной магии. Магическое значение приписывалось анаграмме в древних поэтических текстах. Она выполняла магическую роль табуистической замены сакральных имен. Принцип звуковой мотивации символики

(C) Гура А. В., 2019 
сновидений известен с глубокой древности. Подобные примеры имеются в ассирийских, древнеегипетских, античных, византийских сонниках.

В традиционной символике сновидений рыба у сербов и хорватов получает в качестве прогноза значение заботы, беспокойства на основе анаграммы риба - брига, на Русском Севере толкуется как предвестье плача исходя из анафоры рыба-pыдать, а в Полесье символизирует прибытие гостей по созвучию риба - прибыль. Корова во сне получает в Полесье ассонансные и рифмованные толкования корова - хвороба (символ болезни) или корова - корогва (хоругвь), объясняемая как предвестье болезни или смерти, а также аллитерационное толкование корова - на кровь. У русских символическая связь ее с плачем обусловлена рифмой: (видеть) корову - к рёву. В Вологодской области известно анафоническое снотолкование корова - оброк (напоминание о данном обещании). А на Украине в основе символики коровы как врага лежит анаграмма, почти палиндром: корова - ворог.

В поэтической речи фонетические созвучия выполняют прежде всего формальную роль - ритмическую, эвфоническую и т. п. Б. Эйхенбаум писал, что стих отличается от не-стиха особенностями звукового порядка, а не смыслового. Звуковые средства (рифма, ассонансы и пр.) имели изначально первостепенное значение в образовании стихотворной речи. В «Слове о полку Игореве» А. Ю. Чернов и С. Л. Николаев выявили систему рифмовки, основанную на хендингах, характерных для скальдической поэзии, и обнаружили ряд смысловых рифм, заключающих в себе магию слова, восходящую к наследию волхвов. Князь Игорь, бегущий из плена горностаем, - пример архаического синкретизма магии (оборотничества) и слова - обращения человека в горностая по вербальному созвучию человека и животного: «а Игорь князь поскочи горнастаемъ к тростію».

Магическая функция речи и действенный механизм символизации на основе созвучий присущи также жанру заклинания. Одним из показателей архаики заклинательных формул может служить синкретизм слова и магического действия, когда заклинание представляет собой перформатив, самостоятельный вербальный ритуал. Этимологическую связь слов змија и земља воскрешают сербские заклинательные формулы от змеиного укуса, о которых писал В. Н. Топоров. Их произносят, прикладывая землю к месту укуса: «Земља земљу љуби!»<Земля 
землю целует!>, «Земља земљу јела» <Земля землю (пусть) ест!>. Актуализация смыслового родства слов путем их созвучия задействует и символическую связь между соответствующими реалиями - змеей и землей - по локативному признаку. Звуковая игра в магических целях представлена в заговорах, в которых символическим значением наделяются личные имена, созвучные названиям того, на что направлена сила заклинания: имя Стоян у болгар используется для остановки кровотечения, а Вида у сербов - для лишения зрения, способности видеть дневной свет (видело): «Видо, видело да не видиш!»

Наделение зверька ласки символикой ласковости у поляков Малопольши обусловлено анафорой tasia, tasica 'ласка' и tasić się 'ластиться, ласкаться'. Считается, что за вежливое обращение к ней pani tasia она будет ластиться к человеку и укажет ему клад. Символическими связями обрастает также созвучие названия ласки в Полесье (ласища) с ее действиями по отношению к скоту — ласкать, ласкотать 'щекотать', которые сближают ее с русалкой, полудницей, кикиморой и тому подобными персонажами.

В результате народноэтимологического сближения на звуковой основе символическое значение получают дни недели. В северной Болгарии четверг наделяется символикой прочности, здоровья: в четверг (четвъртък) на основе анафонического созвучия с прилагательным чевръст 'прочный' раздают хлеб при рождении ребенка, чтобы ребенок был крепким (чевръст). А у словенцев Восточной Штирии вторник считался опасным своей демонической силой: невеста не должна была переходить на житье к жениху во вторник (torek, -rka), потому что с ним связано созвучное по названию демоническое существо tork $(l j) \boldsymbol{a}$, которое наказывает пряху за нарушение запрета прясть вечером в определенные дни.

Часто фонетический и логический способы символизации действуют совместно. Так, апотропейная символика бороны в ритуальной магии мотивируется не только ее решетчатостью, острыми зубьями, ячейками и узлами-переплетениями, но и сближением омонимов *borna - как ‘борона' и как 'оборона, защита, преграда', — возможно, сближением вторичным, поскольку разошедшиеся значения, скорее всего, восходят к семантически единому слову. Мотивы воровства в представлениях о воробье связаны с вредом, который он наносит посевам. Отсюда обереги полей от воробьев. Та же символика - в украинской 106 
легенде о том, что птицы за воровство заковали воробью ноги в кандалы, отчего он скачет на обеих ногах. Поддерживается такая символика анафорическим сближением слов воробей и вор. Хтоническая, связанная со смертью символика во́рона определяется его черной окраской и тем, что он питается мертвечиной. У болгар она подкрепляется аллитерацией гарван 'ворон', грача 'каркать' и гроб 'могила'. Отсюда болг. диал. гроб, гробник, гробар 'ворон' и вербальная имитация его крика: «гро! гро!» (т. е. гроб). А у поляков символика кражи применительно к вороне, вызванная ее охотой на цыплят (отчего в гнездо наседке для оберега кладут вороньи перья), мотивируется еще и фонетически - анафорой krakać 'каркать' и kraść 'красть' (ср. также передачу крика вороны «kra-aść!») и анаграммой (анафонией) wrona 'ворона' — porwanie 'похищение', porwać 'похитить, выкрасть'.

Мотивация значения на основе созвучий помогает не только понять архаические механизмы символизации в культуре, но и способствует более полному раскрытию смысловых связей слов в этимологических исследованиях.

DOI $10.31168 / 7996-2700-3.38$

\section{Ю. А. Дзиццойты}

Юго-Осетинский государственный университет им. А. Тибилова

Цхинвал, Республика Южная Осетия dzicc@mail.ru

\section{Реликты мифа о похищении сомы в топонимии Южной Осетии}

1. Топонимические предания осетин являются неотъемлемым сопровождением каждого агиотопонима, играющего сколько-нибудь важную роль в жизни общества. Их историческая ценность весьма условна, поскольку хранящиеся в них сведения не поддаются проверке с помощью существующих исторических источников. Этого нельзя сказать о мифах, представленных в топонимических преданиях: даже те из них, которые сохранились не в полной, завершенной форме, () Дзиццойты Ю. А., 2019 